\title{
NOROVIRUS ON CRUISE SHIPS: SHOULD AMERICANS BE WORRIED?
}

\author{
Bingjie Liu-Lastres \\ Indiana University-Purdue University Indianapolis, USA \\ bliulas@iu.edu \\ and \\ Godwin-Charles Ogbeide \\ Indiana University-Purdue University Indianapolis, USA \\ gogbeide@iu.edu
}

\begin{abstract}
Norovirus, known as "cruise ship virus," has become one of the most significant public health challenges for the cruise industry over the past decade. It is imperative for cruise lines and other sectors within the hospitality industry to learn how to manage health-related issues such as norovirus outbreaks. This case study provides an overview of how the cruise industry has responded to norovirus outbreaks over the years. The goal of this case study is to encourage critical thinking about risk and crisis management within the cruise industry and inspire future cruise ships' leaders in developing risk and crisis management skills.
\end{abstract}

Key Words: Crisis Communication and Management, Cruise Industry, Norovirus, Situational Crisis Communication Theory, Four R' Concept of Crisis Management Health-related Crises

\section{INTRODUCTION}

The cruise industry is one of the rapidly developing and most prosperous areas within the hospitality industry, currently serving as many as 25 million travelers and is reaching growth rates of two-digit levels (UNWTO 2010; Cruise Lines International Association (CLIA), 2018). A 2018 report revealed, the cruise industry, as a whole had a US\$126 billion worldwide economic impact in 2016, which speaks to the cruise industry's notable contributions to the global economy. This impact includes US\$41.1 billion in wages for about one million full-time job roles (CLIA, 2018). The CLIA reported that about 25 million people went on a cruise in 2016 (CLIA, 2018). The cruise industry faces a demand for additional ships and cruise lines as well as increases in carrying capacities to accommodate this influx of travelers and the growth the cruise industry is experiencing globally (CLIA, 2018). Despite the strong growth, the cruise industry has been facing challenges brought by emerging health issues (e.g., norovirus, influenza) over the past decade (World Health Organization, 2018). By reviewing and evaluating cruise lines' practices, this case study aims at providing insights into managing health-related crises in the cruise industry.

\section{Background Information on the Cruise Industry}

Between 2011 and 2016, there was a 20.5\% increase in global demand for the cruise industry. The passenger capacity of the global cruise market reached 23.14 million in 2016 and was expected to continue to grow to reach 27.2 Million by 2018 (Figure 1). The United States is the leading market for the global cruise industry (Figure 2), and 11.7 million Americans took at least one cruise trip in 2016, which represents a 10 percent increase from 2011 (CLIA, 2017). The U.S. cruise industry generated revenue of $\$ 23.2$ billion in 2015 and is expected to generate revenue of $\$ 31.5$ billion in 2020 (Statista, 2018). Cruise lines' direct expenditures for wages for U.S. employees and taxes paid to U.S. federal, state and local tax jurisdictions increased by nearly 4 percent to $\$ 1.48$ billion, accounting for 6.8 percent of total direct

This is the author's manuscript of the work published in final edited form as:

Liu-Lastres, B., \& Ogbeide, G.-C. (2020). Norovirus on Cruise Ships: Should Americans Be

Worried? Journal of Hospitality \& Tourism Cases, 8(2), 23-33.

https://doi.org/10.4135/9781529761399 
expenditures. In 2017, the most popular length of cruise travel for the U.S market was a 7-day cruise, and the most popular destinations were Caribbean/Bahamas/Bermuda (CLIA, 2017). Over thirty percent of the U.S. passengers in 2017 were over 60 years old, and around one-fifth of them were between 20-39 years old. Most U.S. passengers in 2017 came from Florida, California, and Texas.

Figure 1.

2018 Global Passengers Snapshot (in millions)

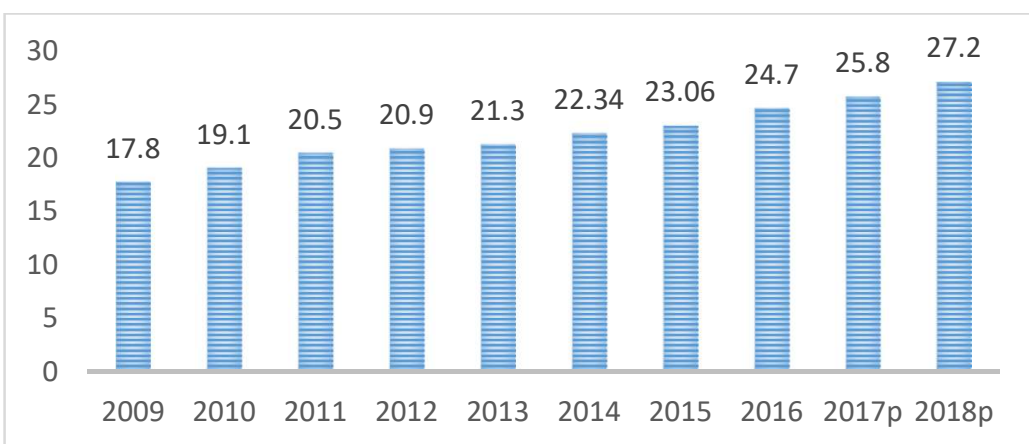

Source: CLIA, 2018

Figure 2.

Number of Cruise Ships Passengers Sources in 2016 (in millions)

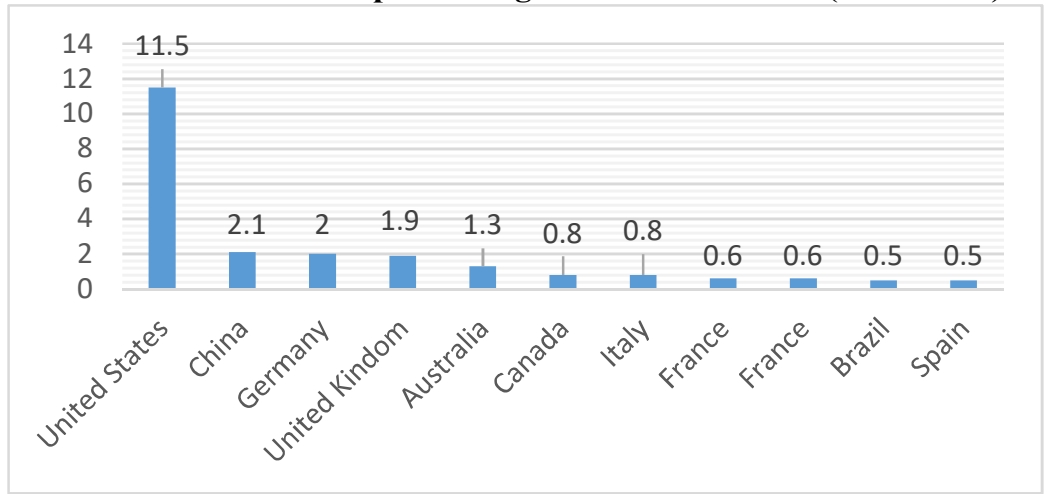

Source: CLIA, 2018

\section{Background Information on Health-Related Crises on Cruise Ships}

Despite their high demand and steady growth, cruise ships are not spared when it comes to health issues and the risk of disease outbreaks (Bert et al., 2014). Without proper management and control, a health risk can cause an illness outbreak on board, which can further escalate into a crisis for the cruise line (Bert et al., 2014; Liu \& Pennington-Gray, 2017). The event of a health crisis can not only cause an epidemic impact on cruise lines but can even affect the cruise industry as a whole. Dissatisfied passengers, as well as harm to crew members' health and welfare are direct results of a health crisis.

Particularly, the cruise industry has battled for years with norovirus, one of the typical health issues closely associated with cruise travel (World Health Organization, 2018). Government, cruise lines, and other related agencies (e.g., CDC) have undertaken multiple measures (e.g., monitoring, passenger health prescreening) to manage norovirus outbreaks on cruise ships. The results, however, are inconsistent. The issue 
has not been completely eliminated, and the public still considers cruise travel unsafe because of norovirus (Harris Poll, 2014).

\section{Crisis and Health-Related Crises}

A crisis can be defined as "the perception of an unpredictable event that threatens important expectancies of stakeholders and can seriously impact an organization's performance and generate negative outcomes" (Coombs, 2014, p. 2). Crises are perceptual, unpredictable, and capable of causing negative consequences and violating stakeholders' expectations (Coombs, 2014). Similarly, crisis events are detrimental in a tourism context. A tourism crisis not only disrupts organizations' normal operation, but also can lead to adverse effects on hospitality products' attractiveness, safety, and appeal (Santana, 2004). A wide variety of crises has been studied, ranging from natural disasters, technological or man-made crises, healthrelated crises, to conflict-based incidents (Pennington-Gray \& Pizam, 2011). Particularly, health-related crises can be divided into three types: (1) epidemic diseases, which can quickly spread among people (e.g., influenza), (2) pandemic diseases, which are normally on a large scale and can spread through populations across different areas (e.g., cholera, smallpox), and (3) endemic diseases, which are normally confined within certain locations (Pennington-Gray \& Pizam, 2011). Additionally, based on the way of transmission, diseases can be categorized as (1) food-borne diseases (e.g., norovirus, salmonellosis, botulism), (2) water-borne diseases (e.g., cholera, enterotoxigenic Escherichia coli, typhoid) and (3) respiratory infections (e.g., avian flu, Legionnaires' disease).

Health-related emergencies are often coupled with disastrous consequences. The event of an outbreak or health-related crisis may prompt individual concerns about possible health risks (Henderson, 2007). If there is an uptick in the degree of perceived health risk, it may lead to behavioral shifts such as altering travel plans and destination, canceling travel arrangements or demanding refunds (Marti, 1995). Additionally, institutional consequences may follow health-related crises and can be divided into two levels: the firm level and the destination level (Williams \& Ballaz, 2014). At a firm level, outcomes involve disturbances in normal operations, drops in revenue and market recession; while at the destination level outcomes involve possible drops in visitor numbers and a combination of an unsafe or adverse destinationbrand perception. These two kinds of impacts are actively connected because the service industry (firm level) at a given destination (destination level) primarily relies on the numerous hospitality organizations (Williams \& Ballaz, 2014).

\section{What is Norovirus (NoV)?}

Norovirus serves as the leading cause of human acute viral gastroenteritis (Neri, Cramer, Vaughn, Vinjé, \& Mainzer, 2008). Normal signs and symptoms of norovirus infection include nausea, vomiting, abdominal pain, diarrhea, malaise, and muscle pain; in some occasions, complications or even death may occur (Neri et al., 2008). There is no specific medicine to treat people with norovirus illness, and it is usually self-limiting. Norovirus is highly contagious and can be transmitted quickly via various paths, such as consuming contaminated food and drink, physical contact with sick people and/or objects they have touched, and even an airborne transmission (CDC, 2017). Norovirus outbreaks are relatively common on cruise ships. As shown in Table 1, norovirus is the leading cause of gastrointestinal outbreaks on cruise ships. Additionally, a norovirus outbreak sometimes may involve a larger population that is beyond a cruise ship. Port visits and other related touristic activities allow sick passengers to interact with other passengers and local residents, who have thereby exposed the risk of infection and leading to a more severe epidemic impact of an outbreak (Vivancos et al., 2010).

\section{CDC's Vessel Sanitation Program (VSP)}


The Center for Disease Control and Prevention (CDC) is a federal agency that conducts and supports health promotion, prevention, and preparedness activities in the United States, with the goal of improving overall public health. The CDC established the VSP to monitor the sanitation status of cruise ships leaving from U.S. ports. As shown in Table 2, the VSP programs aim at assisting the cruise industry in preventing and controlling the outbreaks of gastrointestinal illness (GI) on cruise ships (CDC, 2017). The VSP program conducts unannounced inspections of cruise ships and releases the score to the public (https://wwwn.cdc.gov/InspectionQueryTool/InspectionSearch.aspx). At the same time, the CDC provides information on healthy cruising, basic information related to norovirus on cruise ships, and outbreaks updates on their website on a regular basis. Outbreak investigation will be conducted when three percent or more of a cruise ship's passengers or crew member reported symptoms of GI.

Table 1.

Outbreaks of Gastrointestinal Illness cases on Cruise Ships

\begin{tabular}{cccccc}
\hline Year & Total \# of outbreaks & \# of NoV outbreaks & Other & Unknown & \% of NoV outbreaks \\
\hline 2003 & 27 & 15 & 10 & 2 & 55.6 \\
2004 & 36 & 17 & 7 & 12 & 47.2 \\
2005 & 19 & 14 & 1 & 4 & 73.7 \\
2006 & 37 & 32 & 4 & 1 & 86.5 \\
2007 & 23 & 17 & 4 & 2 & 73.9 \\
2008 & 15 & 14 & 1 & 0 & 93.3 \\
2009 & 15 & 10 & 2 & 3 & 66.7 \\
2010 & 14 & 8 & 0 & 6 & 57.1 \\
2011 & 14 & 10 & 2 & 2 & 71.4 \\
2012 & 16 & 16 & 1 & 0 & 100 \\
2013 & 9 & 8 & 1 & 0 & 88.9 \\
2014 & 9 & 8 & 1 & 1 & 88.9 \\
2015 & 12 & 12 & 0 & 0 & 100 \\
2016 & 13 & 11 & 1 & 1 & 84.6 \\
2017 & 11 & 9 & 1 & 1 & 81.8 \\
\hline
\end{tabular}

Table 2.

Major Areas for VSP Inspection 
Medical facilities
Potable water systems
Swimming pools and whirlpool spas
Galleys and dining rooms

Child activity centers

Hotel accommodations

Ventilation systems

Common areas of the ship
Documentation for gastrointestinal illness surveillance and medical logs

Procedures from water source to storage until use, water distribution, protection, and any cross-connections, and disinfection process

Filtration, disinfection, general maintenance, and safety

Food protection during sourcing, provisioning, storage, preparation and service; employee health and personal hygiene; facility equipment maintenance, and dishwashing

Properly equipped diaper changing stations, toilets and hand washing stations, facility disinfection, and infection control for ill children

Routine cleaning sequences and infection control procedures during outbreaks of gastrointestinal illness, including the use of appropriate disinfectants and outbreak policies

System maintenance and system cleaning

Integrated pest management strategies, general cleanliness, and maintenance

A cruise lines scores $>85$ indicates satisfactory inspection (Data Source: CDC, 2018)

Throughout the last 30 years, the VSP has seen some revisions, the most recent one being the VSP 2011 Operations Manual. Its additions include developing trends in modern technology, high-level food science, and arising pathogens. The VSP is responsible for grading vessels after an inspection based on various standards. The VSP publishes the scores each ship receives in the Summary of Sanitation Inspector of International Cruise Ships. Additionally, outbreaks, where at least 3\% of a cruise ship's passengers or crew members show gastrointestinal or uncommon symptoms, are recorded in weekly bulletins by the VSP (CDC, 2015). The VSP proves to be a successful program with respect to controlling gastronomical illness outbreaks on cruise ships. The major cruise lines all have reached satisfactory inspection scores $(>85)$ in the past five years.

\section{The Media's Perspectives}

Due to newsworthiness, the media has paid constant attention to norovirus outbreaks on cruise ships. Examples of norovirus-related reports include (1): the case of Holland America, which had four successive outbreaks in 2002 and was nicknamed "barf boat" by the media; (2) the norovirus outbreak on Carnival Triumph in 2013, whereby the ship was referenced to as "the poop cruise" (CNN News, 2013); (3) the norovirus incident on Royal Caribbean in 2014, where the media named it "Barf Cruise" (CNN News, 2014); and (4) the two consecutive incidences in December 2017 on a Royal Caribbean cruise ship, where more than 532 passengers became ill and five were hospitalized (NBC News, 2017). As suggested by the framework of social amplification of risk, the media has the capability of transforming health incidents into a major crisis, which may exert disruptive effects on a company and an industry (Kasperson, Kasperson, Pidgeon, \& Slovic, 2003). This is evident in the current case. Cumulatively, there has been a close association between norovirus and cruise ships, whereby norovirus has earned itself the nickname of "cruise ship virus." Consequently, such perception may have increased people's perceived risk of cruise travel, and therefore, influence their decisions of taking cruises and choices of specific cruise lines.

\section{SHOULD AMERICANS BE WORRIED ABOUT NOROVIRUS ON CRUISE SHIPS?}

Although the cruise industry has responded to the norovirus outbreaks and has undertaken several preventive measures in the past five years, the public's concerns towards norovirus outbreaks on cruise 
ships cannot be ignored. Although the global demand of cruising has increased 20.5\% from 2011- 2016, results of marketing surveys (e.g., Condo Nest, 2016; Harris Poll, 2014) indicate that Americans are still worried about norovirus infections and therefore, appear to be reluctant of taking cruises. This is especially true for people who haven't cruised before. It seems that they will easily be scared away and wouldn't try cruising because of health issues.

Additionally, some academic studies analyzing passengers' behaviors during norovirus outbreaks on cruise ships found that the majority of passengers misbehave during a norovirus outbreak - they hide their symptoms from the crew members and often delay reporting their sickness (Neri et al., 2008; Wikswo et al., 2011). Such misbehaviors sometimes make the situation more complex and hard to control. Another study examining passengers' safety perception noted that although most passengers are not worried about their health and safety while cruising, they actually do not know much about potential health issues on board (Baker \& Stockton, 2013). Similarly, they do not actively engage in any health-related preventive measures, nor do they have sufficient knowledge about how to protect themselves against health risks on cruise ships (Baker \& Stockton, 2013).

Obviously, the population of Americans cruising and the revenue from cruises continue to increase (Statista, 2018). However, many of the potential passengers are concerned about the incidence of norovirus on cruise ships. While the risk of norovirus illness on cruise ships does truly exist, the risk is not actually higher than in similar environment such as resort, workplace, or school (Spinks, 2017). One of the reasons the public associates cruise ships with norovirus is because cruise lines are required to report each outbreak of norovirus on each cruise ship. Coupled with the media's common interest to sensationalize the news, unlike other occurrences of norovirus in a resort, workplace, or school, which are usually not subjected to cruise ship's reporting requirements.

\section{DECISION OPTIONS}

Although the cruise industry is booming, a marketing team for cruise ships is worried that the media's undesirable news could negatively affect the industry. The marketing team is considering a great public relations campaign that Americans should not be worried about norovirus infections on cruise ships. On the other hand, some of the members of the marketing team believe that such a campaign will cost a lot of money and it is unnecessary at this point in time when the cruise industry is booming. The marketing team must make a decision about what to do, and these are the options the team is considering:

1. Start a public relations campaign that Americans should not be worried about norovirus infections on cruise ships.

2. Consider a public relations campaign that Americans should not be worried about norovirus infections on cruise ships only when demand declines.

3. Continue the business as is without any public relations campaign.

First Option: Start a public relations campaign that Americans should not be worried about norovirus infections on cruise ships. The idea behind this option is to educate the public about the role of VSP to curtail norovirus on cruise ships. This will include VSP scorecard, which allows a potential passenger to search for the sanitation scores of the cruise ship she/he is thinking of reserving. Any score less than 85 out of 100 is considered unsatisfactory by VSP standard. In addition, the marketing team wants to use the fact that VSP systems are very detailed with many data to instruct potential cruise ship passengers on how easy it is for them to verify if a chosen cruise ship has had any outbreaks of norovirus within any period they wish to know. The VSP requires all the cruise ships from a foreign port to a U.S. port to report any incidence of norovirus within 24 hours. The goal of this campaign is to restore or maintain the public's confidence in cruise ship health and safety by highlighting the fact that cruise passenger has about a 1 in 5,500 risk of getting a laboratory-confirmed norovirus during a shipboard outbreak (see Table 3). 
Table 3.

Organizations with Norovirus Illness

\begin{tabular}{l|cccccc}
\hline Organization & $\begin{array}{c}\text { Health Care } \\
\text { Facility }\end{array}$ & Restaurant & Other & $\begin{array}{c}\text { School/Day- } \\
\text { Care }\end{array}$ & $\begin{array}{c}\text { Private } \\
\text { Residence }\end{array}$ & $\begin{array}{c}\text { On a Cruise } \\
\text { Ship }\end{array}$ \\
\hline Overall \% & $62 \%$ & $22 \%$ & $7 \%$ & $6 \%$ & $2 \%$ & $0.18 \%$ \\
\hline \multicolumn{1}{r}{} & & & Source: CDC National Outbreak Reporting System
\end{tabular}

Second Option: Consider a public relations campaign that Americans should not be worried about norovirus infections on cruise ships only when demand declines. The goal of the option is similar to the above goal for the exception that the campaign will only be employed when the cruise line starts to see declining sales.

Third Option: Continue the business as is without any public relations campaign. This option is the opposite of the first option. The premise behind this option is that any campaign about norovirus will bring about unnecessary negative attention to the cruise industry. The marketing team relies on the consumer's ability to know if norovirus is a concern Americans should be worried about or not. The team believes that a campaign will be expensive and unnecessary now when the cruise industry is booming.

\section{THEORETICAL FRAMEWORKS}

\section{Crisis Communication Practices}

Cruise ships implementing sanitation programs help create a stable framework for preventing, observing, and managing health risks. It is not easy to promote cruise ships when health-related crises like norovirus have prompted copious amounts of media coverage in recent years. For this reason, an extensive crisis management plan built around both sanitation and public health operations and precise communication strategies is vital (Bert et al., 2014; Liu \& Pennington-Gray, 2017). Based on the importance of internal and external communication in regard to this issue, the marketing team decided to explore the importance of situational crisis communication theory in the proposed campaign.

\section{Situational Crisis Communication Theory (SCCT)}

A cruise line's response to a crisis is crucial in rectifying the issue in the eyes of the public to protect reputation and brand image and expedite the recovery process (Coombs, 2014). Hence, the way crisis managers respond to a crisis should match the level of threat propounded by the crisis. Bearing the above in mind, the marketing team is aware of the power of the campaign and tries to identify the best content of the message.

Particularly, Situational Crisis Communication Theory (SCCT) is one of the most widely applied theoretical frameworks in crisis communication (Avery, Lariscy, Kim, \& Hoke, 2010). The SCCT features a situational approach and suggest that an effective crisis response should incorporate three elements: (1) instructing information, which aims at explaining the situation and offering public safety information, (2) adjusting information, which includes corrective actions and a sympathetic attitude, and (3) reputational management strategies, which involves various postures (e.g., Denial, Diminishing, and Rebuilding) (Coombs, 2014).

When it comes to the case of norovirus outbreaks on cruise ships, a previous study (Liu, Pennington-Gray, \& Krieger, 2016) found that individuals, including passengers and potential passengers, have the tendency to attribute the responsibility of the outbreak to the cruise line. Given the high responsibility, cruise lines are expected to provide responses that have (1) instructing information, (2) adjusting information, and (3) rebuilding crisis response strategies (e.g., compensation, apology). An empirical study examining cruise lines' responses (Liu \& Pennington-Gray, 2017) suggest that most cruise 
lines only use adjusting information and rebuilding strategies in their response, while instructing information, as an essential element, has been omitted. Without public safety information, the public may still feel anxious about the problem, and therefore, remain worried (Liu \& Pennington-Gray, 2017).

Armed with the above information from the SCCT and the findings of relevant studies, the marketing team was more convinced to initiate a public relations campaign that would utilize the three sequential categories of crisis communication, to educate Americans to not be worried about norovirus infections on cruise ships. The marketing team understands that effective crisis response can protect organizations' reputational assets and lessen the negative impacts. Hence, the team intends to combine the proposed public relation campaign with the 'Four R' concept of crisis management.

\section{The 'Four R' Concept of Crisis Management}

A comprehensive tourism crisis management model requires efforts in the following four aspects of managing crises: risk reduction, readiness, response, and recovery.

In terms of risk reduction, all cruise lines require passengers to complete pre-boarding health screenings. The Food and Beverage Manager/Catering officer on cruise ships also requires crew members to clean the restaurant on a regular basis and encourage passengers to use hand sanitizers every time they enter the dining area.

In terms of increasing readiness, most cruise ships now are equipped with medical facilities. Cruise ships also carry medical staff/doctors that have received training from medical and public health specialists. While at sea, an incident team is normally formed, which includes the ship's doctor, ship's master of Deputy, Ship's Executive Purser or hotel manager, Ship's F\&B or catering officer, Ship's chief technical staff, and sometimes tour company representative and company health officers.

The response phase involves internal communication and external communication. Internal communication deals with three aspects: (1) communication among the staff on board, (2) communication with passengers on the ship, and (3) communication with the port. CDC requires cruise ships to report an outbreak if more than three percent of passengers/crewmembers experience symptoms of norovirus infections. If an outbreak occurs, the incident team needs to take charge of the situation and implement control measures such as checking on passengers, applying treatments, and stopping all self-service of food to passengers and crew. External communication largely involves how cruise lines respond to this issue to the public. It is important because how a cruise line's public relations (PR) statement addressing this issue is highly visible and determines how the public thinks about the situation, the cruise line, and cruise travel. Previously, the PR teams of cruise lines tend to deny the responsibility for the incidents and blame passengers for bringing the virus on board (Liu et al., 2016). Recently, there has been a change in their PR statements, which are more likely to apologize and compensate the affected passengers instead of simply denial (Liu \& PenningtonGray, 2017).

When it comes to recovery, most cruise ships are allowed to get back on the sail as long as they pass the investigation operated by CDC. At a collective level, the cruise industry is displaying an open and communicative attitude. In 2013, CLIA launched a CruiseFoward website to provide cruise safety information to the public. Currently, CLIA's webpage has specific sections devoted to delivering correct information about norovirus on cruise ships (https://www.cruising.org/cruise-vacationer/industryfacts/norovirus-on-cruise-ships). Washing hands and using hand sanitizers are one of the most effective ways to prevent norovirus outbreaks on cruise ships. Instead of simply providing information online, cruise lines have established multiple innovative programs to promote these activities among passengers. For example, Norwegian cruise line launched a "washy washy" program whereby crew members would sing 
the song in restaurants and encourage passengers to use hand sanitizers. These practices are carried out during the recovery phase but could aid in reducing the possibility of another outbreak on board.

\section{DISCUSSION QUESTIONS}

1. Should Americans be worried about norovirus on cruise ships? Why?

2. Is norovirus a cruise ship problem as it seems? Why?

3. Is cruise vacation still safe? Why?

4. Given the increasing demand of cruising,

a. Should cruise lines worry about norovirus on cruise ships? Why?

b. How would cruise lines secure public confidence to take cruises?

5. Should sick prone people not take cruises in order to avoid potential norovirus issues? Why?

6. In the case study, three decision options were proposed, which option do you think the cruise line marketing team should take? Why?

7. Identify a recent norovirus outbreak on cruise ships, analyze the situation (i.e., how many passengers were infected, how the incident was reported in the media), evaluate the cruise line's response, and propose a brief public relations campaign.

8. Propose a risk and crisis management plan addressing norovirus outbreaks on cruise ships.

9. If norovirus outbreaks occur in other accommodations facilities such as resorts, how would you deal with the situation? 
TEACHING NOTES

Norovirus on Cruise Ships: Should Americans be Worried?

\section{Summary of the Case Study}

This case study offers an interesting situation about norovirus, known as "cruise ship virus," which has become a significant public health issue for the cruise industry over the past decade. The cruise industry is one of the rapidly evolving and most flourishing areas within the hospitality industry, currently serving about 25 million travelers per year in the United States and continues to grow. In 2016, the cruise industry as a whole produced US $\$ 126$ billion in economic impact globally, which speaks to the cruise industry's remarkable contributions to the global economy. The case study highlights the importance of crisis communication and crisis management in the hospitality and tourism industry with special emphasis on the cruise industry. It provides background information of (1) how the cruise industry responds to norovirus outbreaks over the years, (2) the impact of the VSP program operated by CDC, (3) the media perspectives, and (4) the importance of effective crisis communication strategy to restore stakeholders' confidence.

Although the population of Americans cruising and the revenue from cruise continue to increase, however, many of the potential passengers are concerned about the incidence of norovirus on cruise ships. While the risk of norovirus illness on cruise ships does truly exist, there is a misconception in regard to the amount of norovirus incidences on cruise ships versus similar environment such as resort, workplace, or school (CDC, 2018; Spinks, 2017). The case indicated that one of the reasons that public associates cruise ships with norovirus is because cruise lines are required to report each outbreak of norovirus on each cruise ship, unlike other occurrences of norovirus in a resort, workplace, or school, which are usually not subjected to a public monitoring system. In addition, the media's common interest to sensationalize the news about norovirus contributed to norovirus nickname, "cruise ship virus." Due to the above misconceptions, the marketing team of cruise lines is worried that the media's unfavorable news could negatively affect the cruise line and the industry. The marketing team is considering a public relations campaign that Americans should not be worried about norovirus infections on cruise ships. On the other hand, some of the members of the marketing team believe that such a campaign is unnecessary at this point in time when the cruise industry is booming. The marketing team must make a decision about what to do. The following are the options the team is considering:

1. Start a public relations campaign that Americans should not be worried about norovirus infections on cruise ships.

2. Consider a public relations campaign that Americans should not be worried about norovirus infections on cruise ships only when demand declines.

3. Continue the business as is without any public relations campaign.

\section{Theoretical Frameworks:}

The conceptual frameworks regarding the case include the Situational Crisis Communication Theory and the 'Four R' concept of crisis management. The tenet of the theoretical framework is that the way crisis managers respond to a crisis should match the level of threat faced by the crisis. Bearing the above in mind, the marketing team is aware that in order for the public relations campaign that "Americans should not be worried about norovirus infections on cruise ships" to be successful, the way the campaign is communicated to the passengers, public, and media must match the degree of threat brought about by the crisis.

\section{Teaching Objectives}

By the end of this case study, junior and senior undergraduate, as well as postgraduate students in hospitality and tourism management and as business programs should be able to:

- Understand the importance of crisis communication and management in tourism and hospitality.

- Understand the importance of risk and crisis management in tourism and hospitality.

- Have a basic understanding of relevant theoretical frameworks, such as the Situational Crisis Communication Theory and the "Four R" Tourism Crisis Management Model.

- Critically analyze a crisis situation and propose applicable solutions.

- Evaluate and recommend effective crisis communication plans. 


\section{Target Audience of the Case Study}

This case study provides an opportunity for undergraduate juniors and seniors, and/or postgraduate students in hospitality and tourism management as well as business programs to discuss several management and leadership issues including crisis management, decision making, crisis communication, and stakeholders' morale during crisis, as well as the implications of health-related crises on cruise ships.

\section{Prior to Class}

Prior to class, students will be asked to read the case study and the conceptual framework regarding the case including Situational Crisis Communication Theory, the 'Four R' concept of crisis management, and the three sequential categories of crisis communication content. In addition, they will be urged to prepare to answer the questions following the case and discuss the following:

- Situational Crisis Communication Theory

- The 'Four R' concept of crisis management

- The three sequential categories of crisis communication content

- A respond to stakeholders' concerns during an incidence of norovirus on cruise ships

- The need for effective crisis communication during a time of norovirus infection

Class Instruction: The class instruction for this case can take any of the below two approaches:

\section{Approach I (50 minutes)}

1. Start the class by asking if the students have done the case assignment. Continue with a brief summary of the case and ask whether any of the students have taken a cruise and/or faced the situations in this case (5 minutes).

2. Present a power point presentation about the theoretical concepts that comes with the case. Describe the following concepts: Situational Crisis Communication Theory, the 'Four R' concept of crisis management, and the three sequential categories of crisis communication content (10 minutes).

3. Divide students into small groups (at least 4 groups) and urge each group to answer at least three of the six questions following the case (10 minutes)

4. Let each group present their answers (10 minutes)

5. Reinforce the answers of each group (5 minutes)

6. Class discussion on the implications of health-related crisis on cruise ships (5 minutes)

7. Summary of the case key points (5 minutes)

\section{Approach 2 (75 minutes)}

1. Start the class by asking if the students have done the case assignment. Continue with a brief summary of the case and ask whether any of the students have taken a cruise and/or faced the situations in this case. (10 minutes).

2. Then, ask the students to form small groups (at least 4 groups). Ask each group to debrief the case study by discussing the following topics and answer the six questions following the case (15 minutes)

a. What is the case study about?

b. Background information about cruise ships

c. General information about norovirus

d. Theoretical concepts regarding the case

e. The decision options of the case?

3. Probe the class about the theoretical concepts regarding the case (10 minutes)

4. Let each group present their answers (20 minutes)

5. Reinforce the answers of each group (10 minutes)

6. Class discussion on the implications of health-related crisis on cruise ships (5 minutes)

7. Summary of the case key points (5 minutes) 


\section{Discussion Questions for Use in Class:}

1. Should Americans be worried about norovirus on cruise ships? Why?

$\rightarrow$ The discussion can focus on the negative impacts of a norovirus outbreak on the cruise line.

$\rightarrow$ The discussion can feature multiple perspectives, such as the media, the passenger, and the cruise line. The discussion can also address the differences between the reality and people's perceptions.

2. Is norovirus a cruise ship problem as it seems? Why?

$\rightarrow$ The discussion can address the media effects on people's perceptions and attitudes.

$\rightarrow$ The discussion can surround why the efforts taken by the cruise line industry are not as effective as expected.

$\rightarrow$ The discussion can address the gap between reality and people's perceptions.

3. Is cruise vacation still safe? Why?

$\rightarrow$ The discussion can feature the differences between reality and people's perceptions.

$\rightarrow$ The discussion can expand to areas beyond norovirus outbreaks, such as terrorist attacks, and crime.

4. Given the increasing demand of cruising,

a. Should cruise lines worry about norovirus on cruise ships? Why?

$\rightarrow$ The discussion should surround the potential negative consequences associated with tourism crisis, such as reputational, financial loss.

b. How would cruise lines secure public confidence to take cruises?

$\rightarrow$ The discussion should surround follow the SCCT guidelines and/or the Four R' model.

5. Should sick prone people not take cruises in order to avoid potential norovirus issues? Why?

$\rightarrow$ The discussion should surround the inefficiency of cruise lines' current measure such as prescreening passengers.

$\rightarrow$ The discussion can cover topics such as how to engage the passengers in self-preventive measures.

6. In the case study, three decision options were proposed, which option do you think the cruise line marketing team should take? Why?

$\rightarrow$ The discussion can feature a situational approach and then carefully evaluate the appropriateness of each solution under different circumstances.

7. Identify a recent norovirus outbreak on cruise ships, analyze the situation (i.e., how many passengers were infected, how the incident was reported in the media), evaluate the cruise line's response, and propose a brief public relations campaign.

$\rightarrow$ Follow the SCCT guidelines.

8. Propose a risk and crisis management plan addressing norovirus outbreaks on cruise ships.

$\rightarrow$ Follow the Four R' Tourism Crisis Management Model.

9. If norovirus outbreaks occur in other accommodations facilities such as resorts, how would you deal with the situation?

$\rightarrow$ Follow the SCCT guidelines and the Four R' Tourism Crisis Management Model.

\section{Additional Readings}

1. Situational crisis communication theory: its use in a complex crisis with Scandinavian airlines' grounding of dash 8-q400 airplanes.

2. Coombs, W. T. (2014). Ongoing crisis communication: Planning, managing, and responding. Sage Publications.

3. Acute Gastroenteritis on Cruise Ships - United States, 2008-2014 
4. Everything you need — but don't want — to know about getting sick on a cruise ship

5. CLIA fact-sheet about norovirus on cruise ships (https://www.cruising.org/cruisevacationer/industry-facts/norovirus-on-cruise-ships)

\section{The Truth About Norovirus on Cruise Ships}

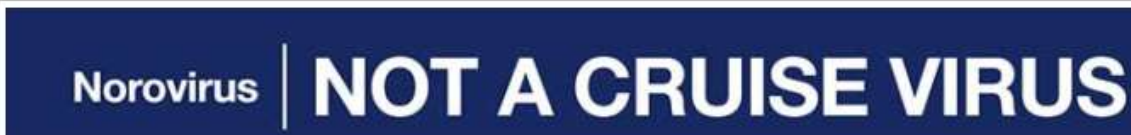

\section{Where People Get Sick from Norovirus}

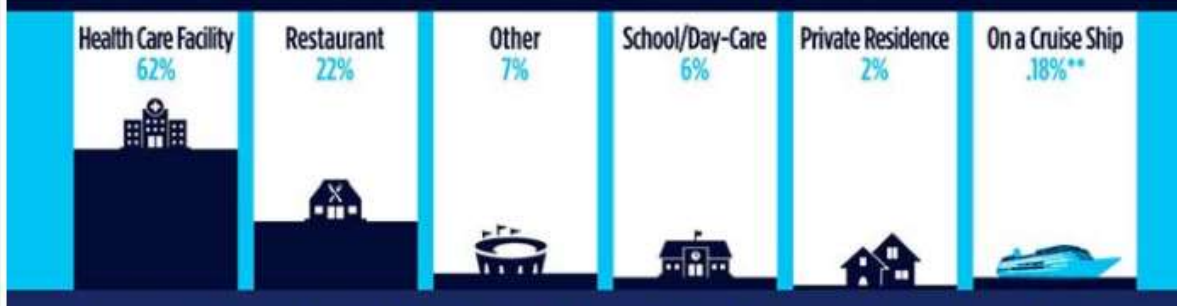

According to statistics, the risk of getting norovirus on land is about 1 in 15. A cruise passenger has about a 1 in 5,500** risk of getting laboratory confirmed norovirus during a shipboard outbreak. 


\section{REFERENCES}

Avery, E. J., Lariscy, R. W., Kim, S., \& Hocke, T. (2010). A quantitative review of crisis communication research in public relations from 1991 to 2009. Public Relations Review, 36(2), 190-192.

Baker, D. M., \& Stockton, S. (2013). Smooth Sailing! Cruise Passengers Demographics and Health Perceptions While Cruising the Eastern Caribbean. International Journal of Business and Social Science, 4(7).

Bert, F., Scaioli, G., Gualano, M. R., Passi, S., Specchia, M. L., Cadeddu, C., ... \& Siliquini, R. (2014). Norovirus outbreaks on commercial cruise ships: a systematic review and new targets for the public health agenda. Food and environmental virology, 6(2), 67-74.

Centers for Disease Control and Prevention. (2017). Facts About Noroviruses on Cruise Ships Retrieved 15th of April 2018 from https://www.cdc.gov/nceh/vsp/pub/norovirus/norovirus.htm

Centers for Disease Control and Prevention. (2018). Vessel Sanitation Program. Retrieved 15th of April 2018 from https://www.cdc.gov/nceh/vsp/pub/norovirus/norovirus.htm

CNN News. (2013). Poop cruise' Carnival Triumph set sail with problems. Retrieved 15th of April 2018 from https://www.cnn.com/

CNN News. (2014). Royal Caribbean cruise ship returns home -- with a sickness record. Retrieved 15th of April 2018 from https://www.cnn.com/

Coombs, W. T. (2014). Ongoing crisis communication: Planning, managing, and responding. Sage Publications.

Condo Nest (2016). Why Americans Don't Cruise. Retrieved 15th of April 2018 from https://www.cntraveler.com/

Cruise Lines International Association. (2017). CLIA US Full Year 2016-2017 Overview. Retrieved 15th of April 2018 from https://www.cruising.org/about-the-industry/research

Cruise Lines International Association (2018). 2018 CLIA State of the Industry. Retrieved 15th of April 2018 from https://www.cruising.org/about-the-industry/research

Harris Poll (2014). Cruise Industry Continues to Battle Unfavorable Tides. Retrieved 15th of April 2018 from https://www.prnewswire.com/news-releases/cruise-industry-continues-to-battle-unfavorabletides-254494811.html

Henderson, J. C. (2007). Tourism crises: causes, consequences and management. Routledge.

Kasperson, J. X., Kasperson, R. E., Pidgeon, N., \& Slovic, P. (2003). The social amplification of risk: assessing fifteen years of research and theory. The social amplification of risk, 1, 13-46.

Liu, B., \& Pennington-Gray, L. (2017). 14 Managing Health-related Crises in the Cruise Industry. Cruise Ship Tourism, 220-237.

Liu, B., Pennington-Gray, L., \& Krieger, J. (2016). Tourism crisis management: Can the Extended Parallel Process Model be used to understand crisis responses in the cruise industry?. Tourism Management, 55, 310-321.

Marti, B. E. (1995). The cruise ship vessel sanitation program. Journal of Travel Research, 33(4), 29-38.

NBC News. (2017). More than 500 people fell sick aboard two Royal Caribbean cruises. Retrieved 15th of April 2018 from https://www.nbcnews.com/

Neri, A. J., Cramer, E. H., Vaughan, G. H., Vinjé, J., \& Mainzer, H. M. (2008). Passenger behaviors during norovirus outbreaks on cruise ships. Journal of travel medicine, 15(3), 172-176.

Pennington-Gray, L., \& Pizam, A. (2011). 19 Destination Crisis Management. Tourism Destination Marketing and Management: Collaborative Stratagies, 314.

Santana, G. (2004). Crisis management and tourism: Beyond the rhetoric. Journal of Travel \& Tourism Marketing, 15(4), 299-321.

Spinks, R. (2017). Everything you need—but don't want— to know about getting sick on a cruise ship. Retrieved $12^{\text {th }}$ of April from https://quartzy.qz.com/1160465/norovirus-on-cruise-ships-how-ithappens-and-how-not-to-get-it/

Statista (2018). Cruise industry - Statistics \& Facts. Retrieved 15th of April 2018 from https://www.statista.com/topics/1004/cruise-industry/

Vivancos, R., Keenan, A., Sopwith, W., Smith, K., Quigley, C., Mutton, K., ... \& Verhoef, L. (2010). Norovirus outbreak in a cruise ship sailing around the British Isles: investigation and multi-agency management of an international outbreak. Journal of Infection, 60(6), 478-485.

Williams, A.M., \& Baláž, V. (2014) Tourism risk and uncertainty: theoretical reflections, Journal of Travel Research,54, (3), 271--28

Wikswo, M. E., Cortes, J., Hall, A. J., Vaughan, G., Howard, C., Gregoricus, N., \& Cramer, E. H. (2011). 
Disease transmission and passenger behaviors during a high morbidity Norovirus outbreak on a cruise ship, January 2009. Clinical infectious diseases, 52(9), 1116-1122.

World Health Organization (2018). Travel by Sea. Retrieved 15th of April 2018 from http://www.who.int/ith/mode_of travel/sea travel/en/

World Tourism Organization (UNWTO) (2010). Cruise Tourism - Current Situation and Trends. Retrieved 15th of April 2018 from https://www.e-unwto.org/doi/book/10.18111/978928441364 